\title{
BALTIC SEA LEVEL CHANGES FROM SATELLITE ALTIMETRY DATA BASED ON THE OptD METHOD
}

\author{
Katarzyna PAJAK ${ }^{1)}$ *and Wioleta BLASZCZAK-BAK ${ }^{2)}$ \\ 1) Institute of Geoinformation and Cartography, Faculty of Geodesy, Geospatial and Civil Engineering, \\ University of Warmia and Mazury in Olsztyn, Oczapowskiego St. 2, Olsztyn, Poland \\ ${ }^{2)}$ Institute of Geodesy, Faculty of Geodesy, Geospatial and Civil Engineering, University of Warmia and Mazury in Olsztyn, \\ Oczapowskiego St. 2, Olsztyn, Poland \\ *Corresponding author's e-mail: katarzyna.pajak@uwm.edu.pl
}

\section{ARTICLE INFO}

\section{Article history}

Received 22 January 2019

Accepted 15 May 2019

Available online 29 May 2019

Keywords:

Optimum Dataset (OptD) method

Satellite altimetry

Sea level changes

\begin{abstract}
The present-day sea-level rise is a major indicator of climate change. The sea level in European seas has risen at a rate of 2.5 to 4 millimeters per year (von Schuckmann et al., 2018). The aim of this paper is to present the sea level variability in the Baltic Sea, as based on satellite altimetry. For this purpose, the paper presents a methodology of the investigation of the Baltic Sea level changes based on the Optimum Dataset (OptD) method. The OptD method was used to identify characteristic points from the analyzed data set. For detailed theoretical and empirical tests, the sea level anomaly was used.

The time series were created from the data set after introducing the OptD method, in the period from January 1993 to December 2017. The time series are then used to characterize sea level trends, and inter-annual and semi-annual variability in the Baltic Sea region.

The results prove that the linear change is higher at points which are located in the northern part of the Baltic Sea, while it is lower at points located in the western part of the Baltic Sea. The average trend is $4.1 \pm 0.2 \mathrm{~mm} / \mathrm{yr}$. However, the annual cycles in the sea level variations measured by altimetry reach maximum values in approximately the same months (November/December) in the whole Baltic Sea area.

We find that there occur substantial regional deviations in sea level depending on the latitude and longitude. Our results confirm the need for research into the sea level variability in the Baltic Sea region.
\end{abstract}

\section{INTRODUCTION}

The sea level rise is an important indicator for climate change, with directly impacts the coastal regions. In situ and satellite observations show that during the past few decades the regional changes of sea level can deviate considerably from the global mean. The trend of global mean sea level during the period of 1993-2016 amounts to $3.3 \mathrm{~mm} / \mathrm{year}$ (Chambers et al., 2017; Legeais et al., 2018).

The altimeter mean sea level trend is corrected for the Glacial Isostatic Adjustment $(-0.3 \mathrm{~mm} /$ year $)$ to take into account the changes of the geoid over the ocean due to the Post Glacial Rebound (Peltier, 2004). The global mean sea level trend uncertainty is $\pm 0.5 \mathrm{~mm} /$ year (Ablain et al., 2015).

Various factors can cause sea level to change at regional or local scales (e.g., Stammer et al., 2013). A dynamic sea level change induced by changes in atmospheric and oceanic circulations is a major cause of contemporary decadal sea level variability as opposed to long term anthropogenic changes, and a large fraction of the dynamic sea level change can be associated with natural internal climate modes in the Earth's coupled climate system (Stammer et al., 2013).
Long records from tide gauges deployed along the world's coastlines constitute the observational evidence of long-term sea level change (see Spada and Galassi, 2012). The tide gauges are unevenly distributed geographically (Holgate et al., 2013). In the Polish coastal zone they are very limited. However, the tide gauges are providing the sea level related only to the coast. The analyses of the sea level change in the all sea area continue to pose a challenge.

The Baltic Sea region is also of particular geodynamical interest because Fennoscandia is still experiencing a significant uplift rate (several millimeters per year) in consequence of the LatePleistocene deglaciation (see Steffen and $\mathrm{Wu}, 2011$ ). Consequently, the Baltic Sea region is characterized by the interaction of different geophysical and oceanographic phenomena. The most evident phenomenon is the glacial isostatic adjustment (GIA) as a consequence of the unloading of ice masses since the last glacial maximum about 21,000 years ago (Peltier, 2004). Due to the large rates of crustal uplift associated with GIA, in this region a large discrepancy is expected to exist between the relative sea level observed at TGs and the absolute sea level revealed by altimetry. Baltic Sea level variability is caused by different climatic and geological factors that render 


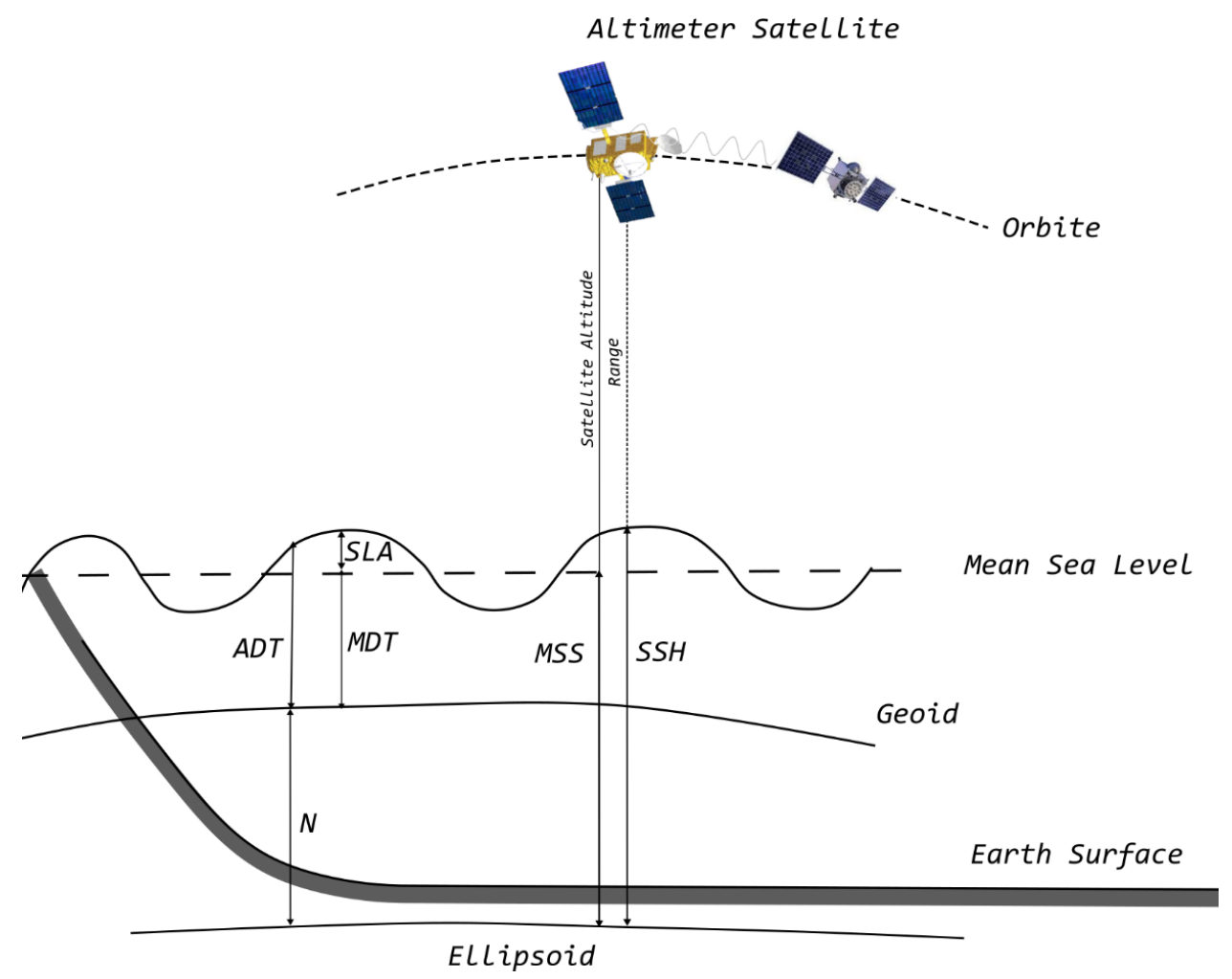

Fig. 1 Scheme of a satellite altimetry measurements (Rocco, 2016; Wooppelmann et al., 2009).

their understanding more difficult than for other areas of the Earth (Hunicke et al., 2017). The sea level changes in the Baltic Sea are predominantly caused by meteorological, atmospherical factors, the local air pressure and strong winds; in the coastal zone the predominantly freshwater inflows may affect Baltic Sea level changes (Snoeijs-Leijonmalm and Andrén, 2017).

In this review, we present a methodology of the investigation of the Baltic Sea level changes based on the Optimum Dataset (OptD) method (Błaszczak-Bak, 2016; Błaszczak-Bąk et al., 2017). The assumption of the method is to reduce the data set without losing the information that is necessary for the correct implementation of the planned task, eg. the development of the DTM, DSM, inventory, thematic maps. The OptD method allows a significant reduction of the data set to preserve the characteristics of the object, and in particular, to obtain points representing the study object. The OptD method is fully automatic; the user only needs to specify the optimization criterion. In this paper the authors have used the OptD method to reduce the huge amount of the satellite altimetry data. Whole data sets were difficult to analyze and it is a challenge to investigate the entire Baltic Sea area. The OptD method, applied in the pre-processing stage, will allow to capture the characteristic values and to preserve the maximum and minimum values in the data sets. The OptD method was used to identify characteristic points from the analyzed satellite altimetry data set. For detailed theoretical and empirical tests, the sea level anomaly was used.
The time series were created from the data set after introducing the OptD method; next, the time series were subjected to advanced statistical analyses. For this purpose, we calculated trends, average differences and standard deviations in the sea level change from satellite altimetry in the 25 -year period in the all analyzed characteristic locations and in the Polish coastal zone locations, were calculated. As time series are characterized by a seasonal signal, in the following stage annual and semi-annual variations were determined. The time series for the period 19932017 of the daily sea level anomaly and time series of the daily sea level anomaly without annual and semiannual signals were presented.

\section{OBSERVATIONS DATA}

In this paper gridded daily sea level anomalies with resolution $0.25 \times 0.25$ degrees and time span from January 1993 to December 2017 were used. The data set obtained from the Copernicus Marine and Environment Monitoring Service (CMEMS) was used. This data set is a product of combined data from several altimetry missions (Legeais et al., 2014). The DUACS system is made of the Delayed-Time (DT also named REP) were made.

In DT, it is to maintain a consistent and userfriendly altimeter database using the state-of-the-art recommendations from the altimetry community. The altimeter measurements used to compute the Sea Level products consist in products from different missions called Delayed Time Geophysical Data Records (GDR) or Non Time Critical (NTC).

The following Figure 1 gives an overview of the satellite altimetry measurements. 
Satellite altimetry measures the time taken by a radar pulse to travel from the satellite antenna to the surface and back to the satellite receiver. Combined with precise satellite location data, altimetry measurements yield sea-surface heights. The altimetry gives access to the Sea Surface Height (SSH) above the reference ellipsoid. The Sea Level Anomaly (SLAN) is the anomaly of the signal around the mean component. It is deduced from the SSH and MSSN:

$$
\mathrm{SLAN}=\mathrm{SSH}-\mathrm{MSSN}
$$

The data set from the satellite measurements has been corrected for atmospheric effects (ionospheric delay and dry/wet tropospheric effects) and geophysical processes (solid, ocean, and pole tides, loading effect of the ocean tides, sea state bias, and the Inverted Barometer response of the ocean), (Fu et al., 2012). Detailed information of the corrections can be found at the AVISO and CMEMS website (http://marine.copernicus.eu/services-portfolio/accessto-products).

\section{OPTIMALIZATION BASED ON OptD METHOD}

The OptD method is a method used to optimize the number of points in data sets (Błaszczak-Bak, 2016; Błaszczak-Bąk et al., 2017). Each point is checked thoroughly before a decision is made to leave it or remove it.

The OptD method was developed with the purpose of taking into account the different levels of reduction in the individual parts of the processing area. In the case of uncomplicated structures or areas, the number of points is much smaller. Only those points that are significant will remain. A very important advantage of the method is the fact that during the processing we have total control over the number of points in the data set. This comes useful in the analysis of the points in a satellite altimetry data set.

A huge amount of data in the satellite altimetry data set makes it difficult to analyze.

The OptD method, applied in the pre-processing stage, will allow to capture the characteristic values and to preserve the maximum and minimum values in the data sets.

Differences (sea level anomaly between the grid points in each month in the 1993 year and 2017 year) are in points with coordinates latitude $(\varphi)$, longitude $(\lambda)$.

1. Points are projected onto the $53^{\circ}>\varphi>65^{\circ}$, $9^{\circ}>\lambda>30^{\circ}$ surface.

2. Determination of the optimization criterion, here: $2 \%$ percent of points in the data set after the reduction. This is the only step that requires input from the user.

3. The surface is divided into measurement strips (L). The value of the measurement strip width is chosen automatically by the OptD method. For individual months it was a different initial value, for January $\mathrm{L}=3.21^{\circ}$, February $\mathrm{L}=1.45^{\circ}$, March $\mathrm{L}=2.35^{\circ}$, April $\mathrm{L}=2.43^{\circ}$, May $\mathrm{L}=1.63^{\circ}$, June $\mathrm{L}=2.82^{\circ}$, July $\mathrm{L}=2.75^{\circ}$, August $\mathrm{L}=1.54^{\circ}$,
September $\mathrm{L}=2.68^{\circ}$, October $\mathrm{L}=1.76^{\circ}$, November $\mathrm{L}=2.21^{\circ}$, December $\mathrm{L}=2.20^{\circ}$.

1. Each strip is considered separately and in each Douglas-Peucker generalization method (Douglas and Peucker, 1973) is executed; however, the generalization takes place in the vertical plane, so as to take into account the sea level anomaly. The result of the generalization depends on the value of the tolerance range $(\mathrm{t})$. For individual months it was a different initial value, for January $\mathrm{t}=32.06 \mathrm{~cm}$, February $\mathrm{t}=9.02 \mathrm{~cm}$, March $\mathrm{t}=9.20 \mathrm{~cm}$, April $\mathrm{t}=15.38 \mathrm{~cm}$, May $\mathrm{t}=8.64 \mathrm{~cm}$, June $\mathrm{t}=8.25 \mathrm{~cm}$, July $\mathrm{t}=7.25 \mathrm{~cm}$, August $\mathrm{t}=8.20 \mathrm{~cm}$, September $\mathrm{t}=11.95 \mathrm{~cm}$, October $\mathrm{t}=16.33 \mathrm{~cm}$, November $\mathrm{t}=25.99 \mathrm{~cm}$, December $\mathrm{t}=30.84 \mathrm{~cm}$.

2. The width of the measurement strip (L) and tolerance $(\mathrm{t})$ are selected in iterations so that the optimization criterion in the form of a given number of points is met. Maximum and minimum values of highs of points are retained because the OptD method will activate the so-called range of the set. If we take into account that is the range is to be narrow (in this case up to $2 \%$ of points), then in effect only characteristic points will remain.

The number of all gridded daily sea level anomalies was 6035 (column 2 in Table 1). However, in the Baltic Sea area the number of sea level anomalies with the registered value was 1374-1651 (column 3 in Table 1). The OptD method was used to optimize this number of points (column 4 in Table 1).

We have obtained characteristic points from the OptD method, in which the biggest differences between the sea level anomalies occur in years 1993 and 2017 for all months. Then, on the basis of these points, time series were generated in the period from January 1993 to December 2017 and statistical approach applied. Final results summarized in Table 1.

Table 1 The number of all gridded daily sea level anomalies, with values and after OptD Metod.

\begin{tabular}{lccc}
\hline Month & $\begin{array}{c}\text { Number } \\
\text { of all sea } \\
\text { level } \\
\text { anomalies }\end{array}$ & $\begin{array}{c}\text { Number } \\
\text { of sea } \\
\text { level } \\
\text { anomalies } \\
\text { with value }\end{array}$ & $\begin{array}{l}\text { Number } \\
\text { of sea level } \\
\text { anomalies } \\
\text { after OptD } \\
\text { method }\end{array}$ \\
\hline January & 6035 & 1651 & 25 \\
February & 6035 & 1374 & 20 \\
March & 6035 & 1548 & 29 \\
April & 6035 & 1421 & 26 \\
May & 6035 & 1403 & 23 \\
June & 6035 & 1403 & 20 \\
July & 6035 & 1403 & 11 \\
August & 6035 & 1415 & 22 \\
September & 6035 & 1403 & 22 \\
October & 6035 & 1403 & 21 \\
November & 6035 & 1403 & 25 \\
December & 6035 & 1496 & 25 \\
\hline
\end{tabular}


(a) January $100 \%$

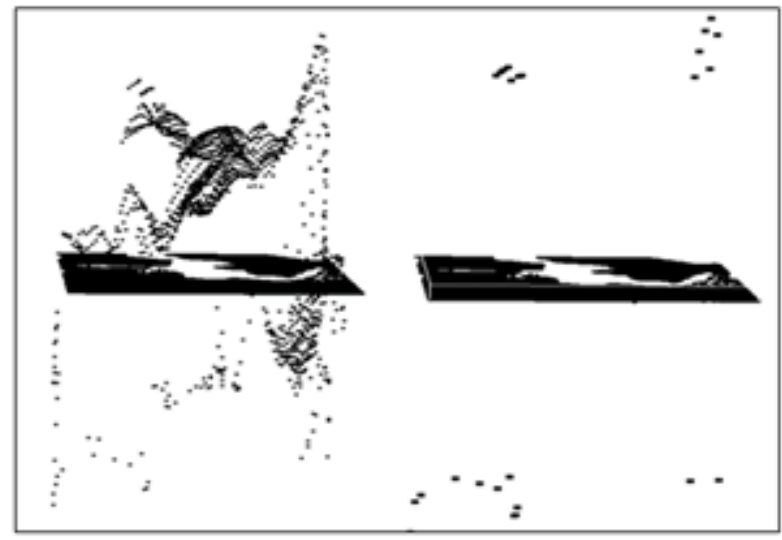

(c) March $100 \%$

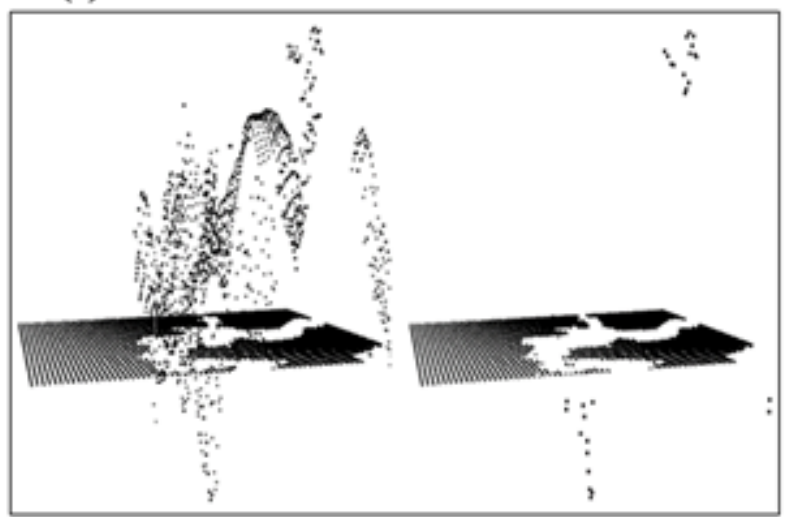

(e) May $100 \%$

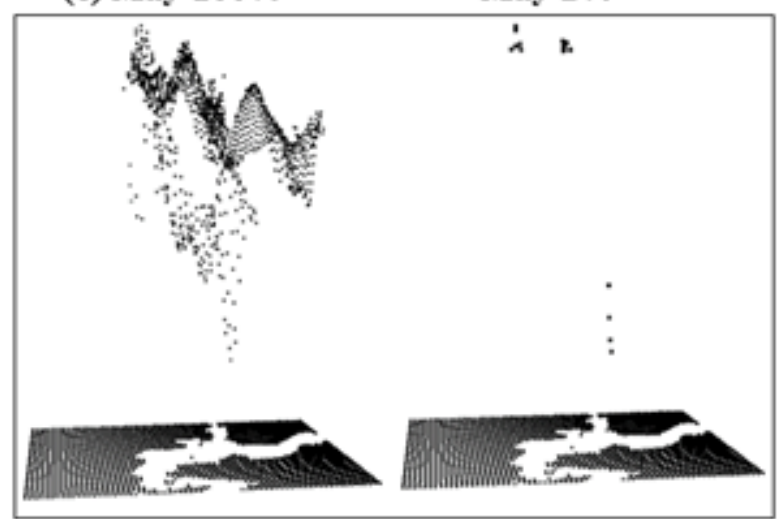

(g) July $100 \%$

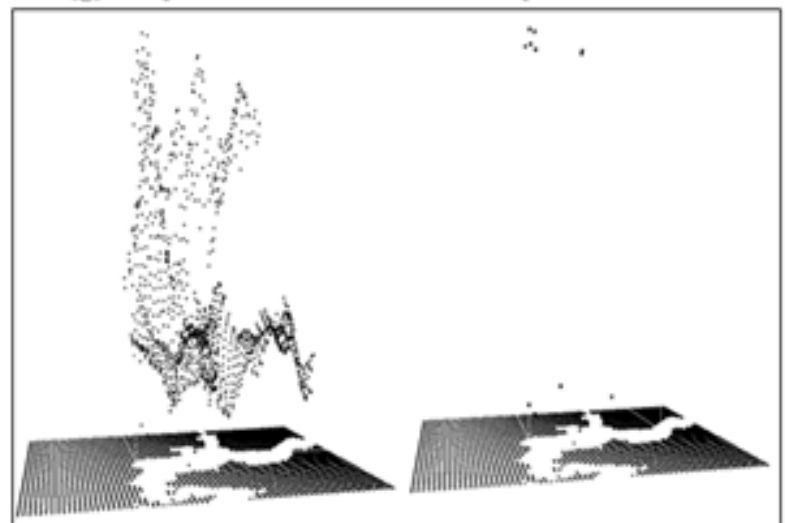

(b) February $100 \%$

February 2\%

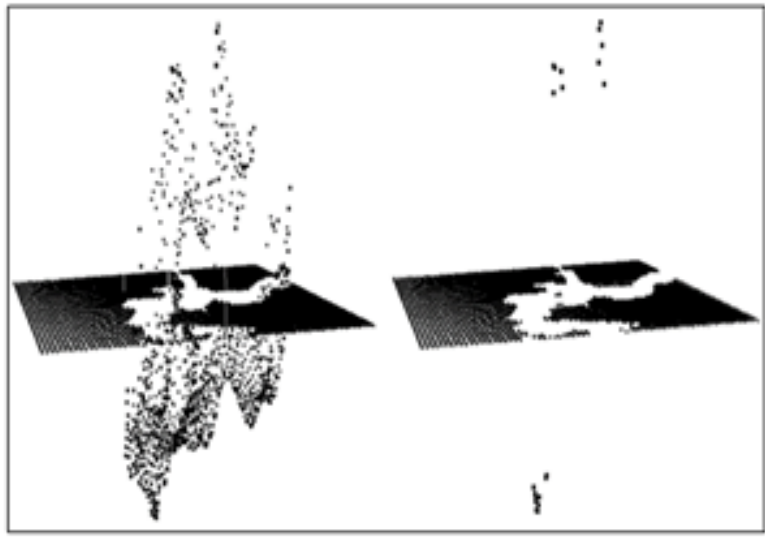

(d) April $100 \%$

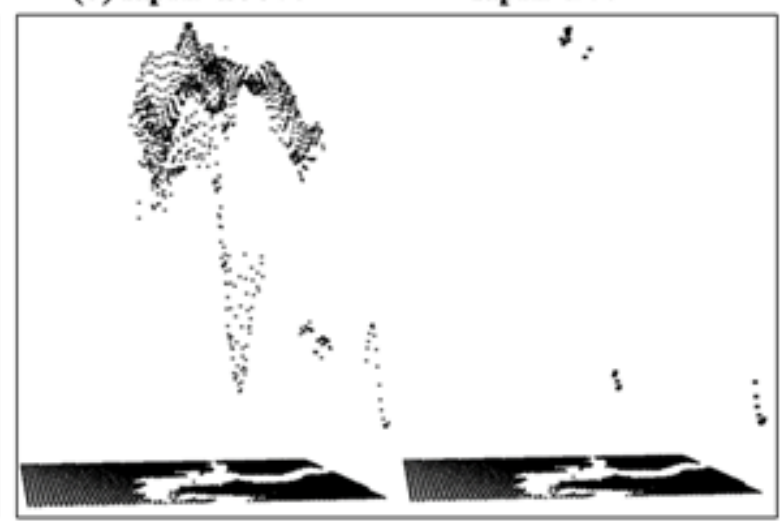

(f) June $100 \%$

June 2\%

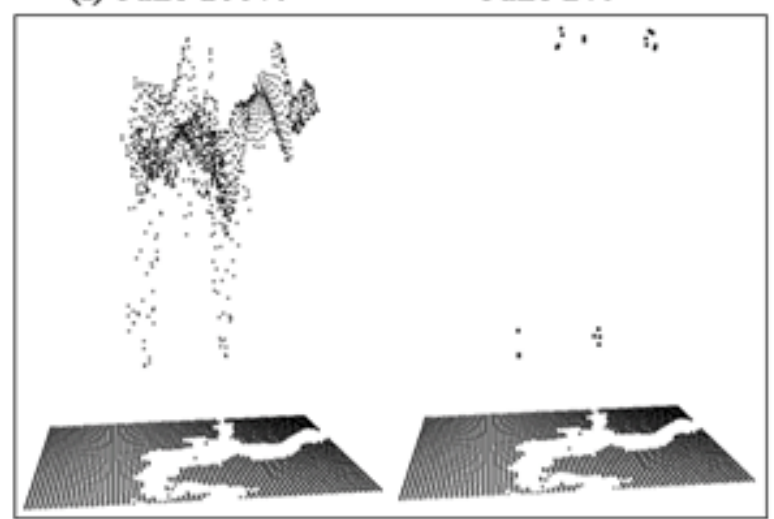

(h) August $100 \%$

August $2 \%$



Fig. 2 The differences between sea level anomalies in years 1993 and 2017 for all months (100\% points and $2 \%$ points). 
(i) September $100 \%$

September $2 \%$

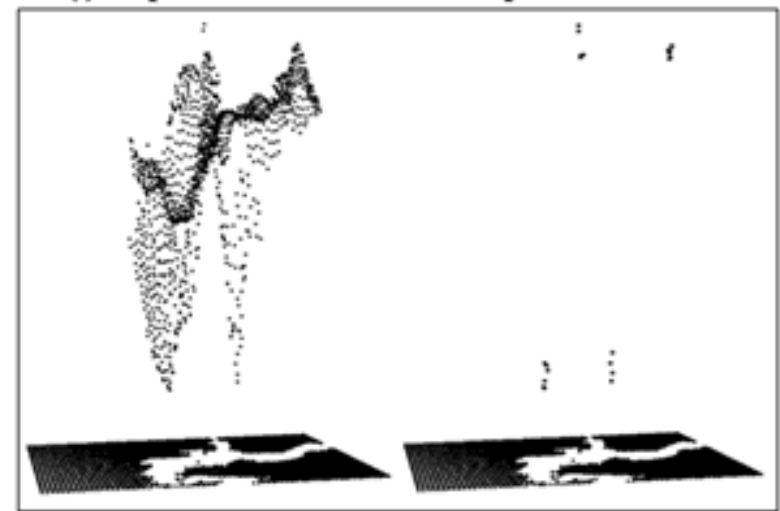

(k) November $100 \%$

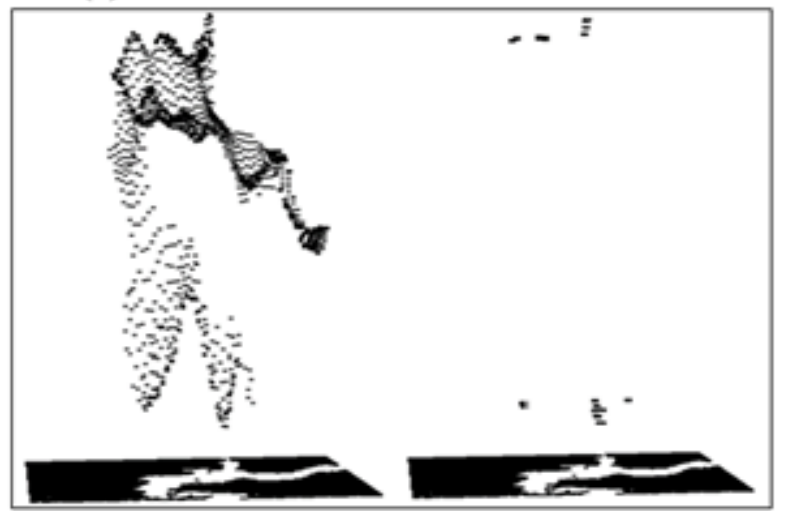

(j) October $100 \%$

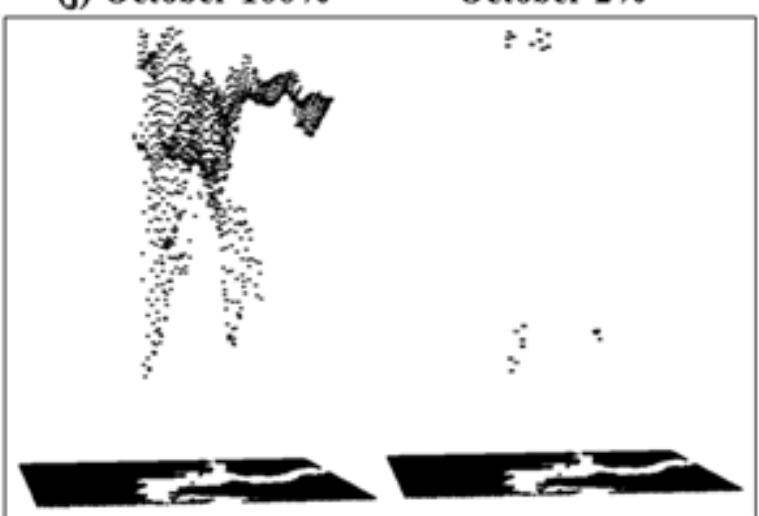

(I) December $100 \%$

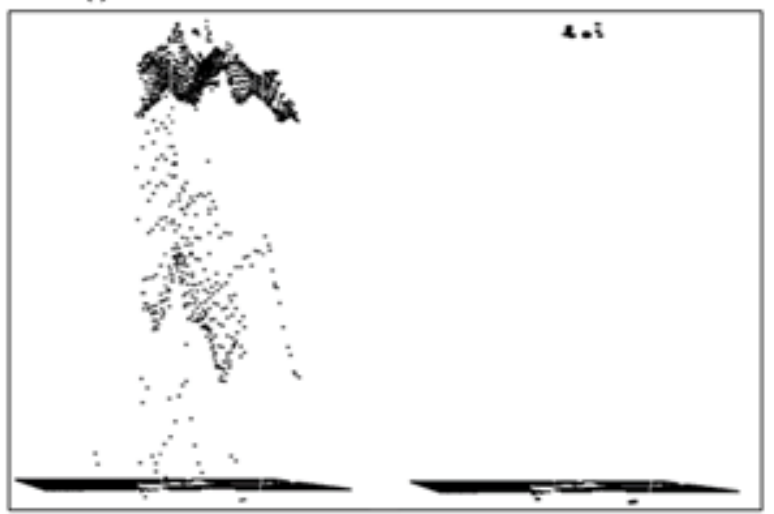

Fig. 2 continued.

Table 2 The selected characteristic points, the maximum differences and the month, when the maximum occurs.

Location

\begin{tabular}{|c|c|c|}
\hline P1 & $5^{4.875^{\circ}} \mathrm{N}$ & 13.125 \\
\hline P2 & $5^{8.125^{\circ}} \mathrm{N}$ & 10.62 \\
\hline P3 & $57.625^{\circ} \mathrm{N}$ & 23.87 \\
\hline P4 & $65.625^{\circ} \mathrm{N}$ & 1002 \\
\hline P5 & $56.375^{\circ} \mathrm{N}$ & 11 \\
\hline P6 & $5^{7.875^{\circ}} \mathrm{N}$ & \\
\hline P7 & $57.625^{\circ} \mathrm{N}$ & 23 \\
\hline P8 & $5^{8.375^{\circ}} \mathrm{N}$ & \\
\hline P9 & $59.625^{\circ} \mathrm{N}$ & 25.8 \\
\hline P10 & $54.375^{\circ} \mathrm{N}$ & 10.375 \\
\hline P11 & $54.375^{\circ} \mathrm{N}$ & 11 \\
\hline P12 & $60.375^{\circ} \mathrm{N}$ & 21.87 \\
\hline P13 & $56.875^{\circ} \mathrm{N}$ & 11.375 \\
\hline P14 & $5^{7.125^{\circ}} \mathrm{N}$ & 23.125 \\
\hline P15 & $64.875^{\circ} \mathrm{N}$ & 23.375 \\
\hline P16 & $58.375^{\circ} \mathrm{N}$ & \\
\hline P18 & $58.625^{\circ} \mathrm{N}$ & 9.8 \\
\hline
\end{tabular}

We have obtained characteristic points from the OptD method, in which the biggest differences between the sea level anomalies occur (Table 2).

Table 2 The selected characteristic points, the maximum differences and the month, when the maximum occurs.

Figure 3 presents the distribution of characteristic points in the area of the Baltic Sea. On the basis of these points, time series were generated in

Month
January
February
February
March
March
April
May
May
July
July
June
November
August
August
September
October
December

the period from January 1993 to December 2017. The time series were subjected to statistical approach; trends of changes, amplitudes and phases were calculated.

Figure 2 shows the surface of the Baltic Sea and visible differences at all GRID points for particular months. As can be noticed, in the winter months the differences are much larger than in the summer months. The widest differences between the sea level 


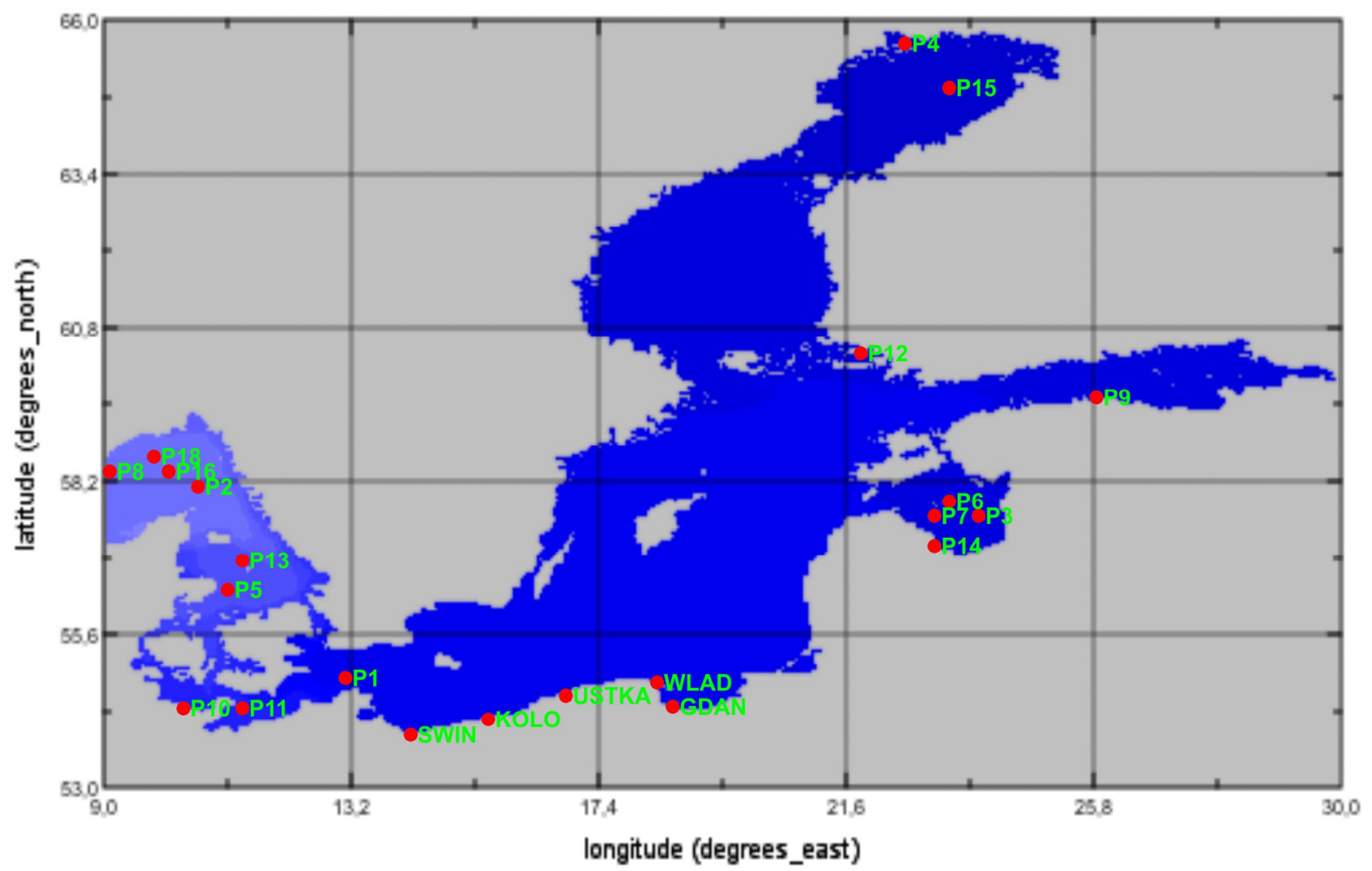

Fig. 3 The Baltic Sea area with the marked characteristic locations and the locations near tide gauge in the Polish coastal zone.

Table 3 Trends, average differences and standard deviations in sea level change from satellite altimetry in the 25 years period.

\begin{tabular}{|c|c|c|c|c|c|}
\hline \multicolumn{3}{|c|}{ Location } & \multirow{2}{*}{$\begin{array}{c}\begin{array}{c}\text { Trend } \\
\text { mm/year }\end{array} \\
3.8 \pm 0.2\end{array}$} & \multirow{2}{*}{$\begin{array}{c}\begin{array}{c}\text { Average } \\
\text { [cm] }\end{array} \\
3.62\end{array}$} & \multirow{2}{*}{$\begin{array}{c}\text { Standard deviations } \\
{[\mathbf{c m}]}\end{array}$} \\
\hline P1 & $54.875^{\circ} \mathrm{N}$ & $13.125^{\circ} \mathrm{E}$ & & & \\
\hline P2 & $58.125^{\circ} \mathrm{N}$ & $10.625^{\circ} \mathrm{E}$ & $3.8 \pm 0.1$ & 3.58 & 8.83 \\
\hline P3 & $57.625^{\circ} \mathrm{N}$ & $23.875^{\circ} \mathrm{E}$ & $4.5 \pm 0.3$ & 3.62 & 18.77 \\
\hline P4 & $65.625^{\circ} \mathrm{N}$ & $22.625^{\circ} \mathrm{E}$ & $5.5 \pm 0.3$ & 4.68 & 17.13 \\
\hline P5 & $56.375^{\circ} \mathrm{N}$ & $11.125^{\circ} \mathrm{E}$ & $4.1 \pm 0.1$ & 3.86 & 10.84 \\
\hline P6 & $57.875^{\circ} \mathrm{N}$ & $23.375^{\circ} \mathrm{E}$ & $4.5 \pm 0.3$ & 3.51 & 18.84 \\
\hline P7 & $57.625^{\circ} \mathrm{N}$ & $23.125^{\circ} \mathrm{E}$ & $4.7 \pm 0.3$ & 3.47 & 18.66 \\
\hline P8 & $58.375^{\circ} \mathrm{N}$ & $9.125^{\circ} \mathrm{E}$ & $3.3 \pm 0.1$ & 3.67 & 6.41 \\
\hline P9 & $59.625^{\circ} \mathrm{N}$ & $25.875^{\circ} \mathrm{E}$ & $4.6 \pm 0.3$ & 3.98 & 17.73 \\
\hline P10 & $54.375^{\circ} \mathrm{N}$ & $10.375^{\circ} \mathrm{E}$ & $2.8 \pm 0.1$ & 3.20 & 8.52 \\
\hline P11 & $54.375^{\circ} \mathrm{N}$ & $11.375^{\circ} \mathrm{E}$ & $3.2 \pm 0.2$ & 3.15 & 11.10 \\
\hline P12 & $60.375^{\circ} \mathrm{N}$ & $21.875^{\circ} \mathrm{E}$ & $4.3 \pm 0.2$ & 3.50 & 16.47 \\
\hline P1? & $56.875^{\circ} \mathrm{N}$ & $11.375^{\circ} \mathrm{E}$ & $4.6 \pm 0.2$ & 3.83 & 10.99 \\
\hline P1 & $57.125^{\circ} \mathrm{N}$ & $23.125^{\circ} \mathrm{E}$ & $4.7 \pm 0.3$ & 3.46 & 18.22 \\
\hline P1: & $64.875^{\circ} \mathrm{N}$ & $23.375^{\circ} \mathrm{E}$ & $5.1 \pm 0.3$ & 3.91 & 17.50 \\
\hline P1 & $58.375^{\circ} \mathrm{N}$ & $10.125^{\circ} \mathrm{E}$ & $2.9 \pm 0.1$ & 3.11 & 9.90 \\
\hline P1 & $58.625^{\circ} \mathrm{N}$ & $9.875^{\circ} \mathrm{E}$ & $3.3 \pm 0.1$ & 3.66 & 6.83 \\
\hline
\end{tabular}

anomalies in 1993 and 2017 occur in the months of January and February.

\section{RESULTS}

In this study, sea level changes in the Baltic Sea area were estimated from the multi-mission satellite altimetry data. We concentrated on the analysis of the sea level change at 17 characteristic locations, which were designated from the OptD method. Also, the 5 locations in the Polish coastal zone were used in the analysis.
The satellite altimetry time series were analyzed at the same time period. In order to analyze the dynamics of the change in sea level, the linear trend estimation was made for the SLA time series (Stammer et al., 2013). Table 3 presents the trend, average differences and standard deviations in all of the analyzed characteristic locations.

A higher linear change occurs at point $\mathrm{P} 4$ and P15, which are located in the northern part of the Baltic Sea (which can be seen in Figure 1). On the other hand, a lower linear change occurs at points P10 
Table 4 Trends, average differences and standard deviations in the sea level change from satellite altimetry in the 25 years period.

\begin{tabular}{|c|c|c|c|c|c|c|}
\hline \multirow{3}{*}{ Location } & \multicolumn{6}{|c|}{ Satellite altimetry (Time span 1993-2017) } \\
\hline & Daily data & $\begin{array}{c}\text { Monthly } \\
\text { data }\end{array}$ & Daily data & $\begin{array}{c}\text { Monthly } \\
\text { data }\end{array}$ & Daily data & $\begin{array}{c}\text { Monthly } \\
\text { data }\end{array}$ \\
\hline & \multicolumn{2}{|c|}{ Trend [mm/year] } & \multicolumn{2}{|c|}{ Average $[\mathrm{cm}]$} & \multicolumn{2}{|c|}{ Standard deviations $[\mathrm{cm}$ ] } \\
\hline SWINOUJSCIE & $3.7 \pm 0.2$ & $3.7 \pm 0.8$ & 3.36 & 3.47 & 13.32 & 10.19 \\
\hline KOLOBRZEG & $4.1 \pm 0.2$ & $4.3 \pm 0.9$ & 3.52 & 3.55 & 14.38 & 11.68 \\
\hline USTKA & $4.1 \pm 0.2$ & $4.3 \pm 1.0$ & 3.54 & 3.51 & 15.33 & 12.58 \\
\hline WLADYSLAWOWO & $4.3 \pm 0.2$ & $4.4 \pm 1.1$ & 3.67 & 3.65 & 15.81 & 13.54 \\
\hline GDANSK & $4.4 \pm 0.2$ & $4.4 \pm 1.0$ & 3.61 & 3.61 & 15.32 & 13.31 \\
\hline
\end{tabular}

Table 5 Results of the satellite altimetry time series fitting, determined for the period $1993-2017$.

\begin{tabular}{lcccc}
\hline Location & $\begin{array}{c}\text { Annual } \\
\text { amplitudes [cm] }\end{array}$ & $\begin{array}{c}\text { Annual phase } \\
\text { [day] }\end{array}$ & $\begin{array}{c}\text { Semi-annual } \\
\text { amplitudes [cm] }\end{array}$ & $\begin{array}{c}\text { Semi-annual } \\
\text { phase [day] }\end{array}$ \\
\hline P1 & $4.47 \pm 1.06$ & -70.20 & $2.82 \div 0.66$ & 34.64 \\
P2 & $7.95 \pm 1.68$ & -60.56 & $0.65 \pm 0.13$ & 29.82 \\
P3 & $7.83 \pm 1.55$ & -50.71 & $5.17 \pm 1.01$ & 21.98 \\
P4 & $\mathbf{8 . 3 1} \pm \mathbf{1 . 8 8}$ & -24.36 & $3.09 \pm 0.60$ & 22.12 \\
P5 & $7.33 \pm 2.11$ & -82.79 & $1.16 \pm 0.24$ & 17.60 \\
P6 & $\mathbf{8 . 2 9} \pm 1.62$ & -47.89 & $\mathbf{5 . 2 8} \pm 1.03$ & 21.57 \\
P7 & $8.22 \pm 1.61$ & -48.44 & $\mathbf{5 . 2 5} \pm 1.03$ & 21.96 \\
P8 & $3.69 \pm 0.72$ & $-46,96$ & $1.24 \pm 0.32$ & 38.07 \\
P9 & $8.08 \pm 1.72$ & -29.50 & $4.81 \pm 1.02$ & 30.88 \\
P10 & $5.82 \pm 1.26$ & -63.52 & $1.36 \pm 0.27$ & 23.33 \\
P11 & $4.05 \pm 1.01$ & -74.04 & $1.92 \pm 0.46$ & 35.36 \\
P12 & $8.04 \pm 1.57$ & -44.06 & $4.19 \pm 0.83$ & 20.05 \\
P13 & $7.58 \pm 2.10$ & -80.38 & $1.30 \pm 0.27$ & 16.38 \\
P14 & $8.07 \pm 1.58$ & -48.67 & $5.11 \pm 1.00$ & 22.13 \\
P15 & $\mathbf{8 . 3 1} \pm \mathbf{1 . 8 5}$ & -25.49 & $4.05 \pm 0.83$ & 28.38 \\
P16 & $5.09 \pm 1.00$ & -50.39 & $1.28 \pm 0.36$ & 40.60 \\
P18 & $4.84 \pm 0.97$ & -53.86 & $1.07 \pm 0.30$ & 39.81 \\
\hline
\end{tabular}

and P16, which are located in the western part of the Baltic Sea. The average trend is $4.1 \pm 0.2 \mathrm{~mm} / \mathrm{yr}$. The 2nd Edition of the Copernicus Marine Service Ocean State Report (OSR) published in 2018 provides information on changes and variations in the ocean over the past decades, with a focus on changes in the marine environment during the year 2016. In the report the mean sea level trends and their uncertainty in the period 1993-2016 for the Baltic Sea for the total altimeter sea level is $4.0 \pm 2.9 \mathrm{~mm} / \mathrm{yr}$. The altimeter trends have been corrected for the glacial isostatic adjustment using the ICE5G-VM2 model (Peltier, 2004). The results are based on the Data Unification and Altimeter Combination System (DUACS) delayed-time altimeter sea level products (two satellites constellation) distributed within the Copernicus Climate Change Service (C3S). These C3S sea level maps are based on a stable number of altimeters (two) in the satellite constellation (von Schuckmann et al., 2018). Furthermore, in this article we present the trend, average and standard deviations in the Polish coastal zone locations (Table 4).

The trends in the Polish coastal zone locations are between $3.7 \pm 0.2 \mathrm{~mm} / \mathrm{yr}$ in the Swinoujscie and $4.4 \pm 0.2 \mathrm{~mm} / \mathrm{yr}$ in the Gdansk. An average present-day rate of vertical motion of the solid earth due to GIA in $\mathrm{mm} / \mathrm{yr}$ : in Swinoujscie 0.28, in Kolobrzeg 0.46, in Ustka 0.55 , in Wladyslawowo 0.55 , and in Gdansk 0.46 (Peltier et al., 2015). When the GIA corrected the average sea level trend in the Polish coastal zone is $3.7 \mathrm{~mm} / \mathrm{yr}$.

All the time the series has a seasonal signal (annual plus semi-annual) and a trend, which can be expressed as follows:

$$
f(t)=a+b \cdot t+A_{a} \cos \left(\omega_{0} t-\phi_{a}\right)+A_{s a} \cos \left(\omega s_{0} t-\phi_{s a}\right)
$$

where $a$ is the bias, $b$ is the trend, $t$ is the time, $A_{a}$ and $A_{s a}$ is the annual and semi-annual amplitudes, $\varphi_{a}$ and $\varphi_{s a}$ is the annual and semi-annual phase, $\omega_{a}$ and $\omega_{s a}$ is the annual and semi-annual angular frequency, respectively (Pollock, 2008). We used the leastsquares method to fit the time series of the sea level variations for every station and estimated the annual and semi-annual items, and the long-term trend of the seasonal sea level variations. The sea level anomaly determined from the satellite altimetry and the fitted seasonal variations are displayed in Figure 4, and the results are collected in Table 5 . 

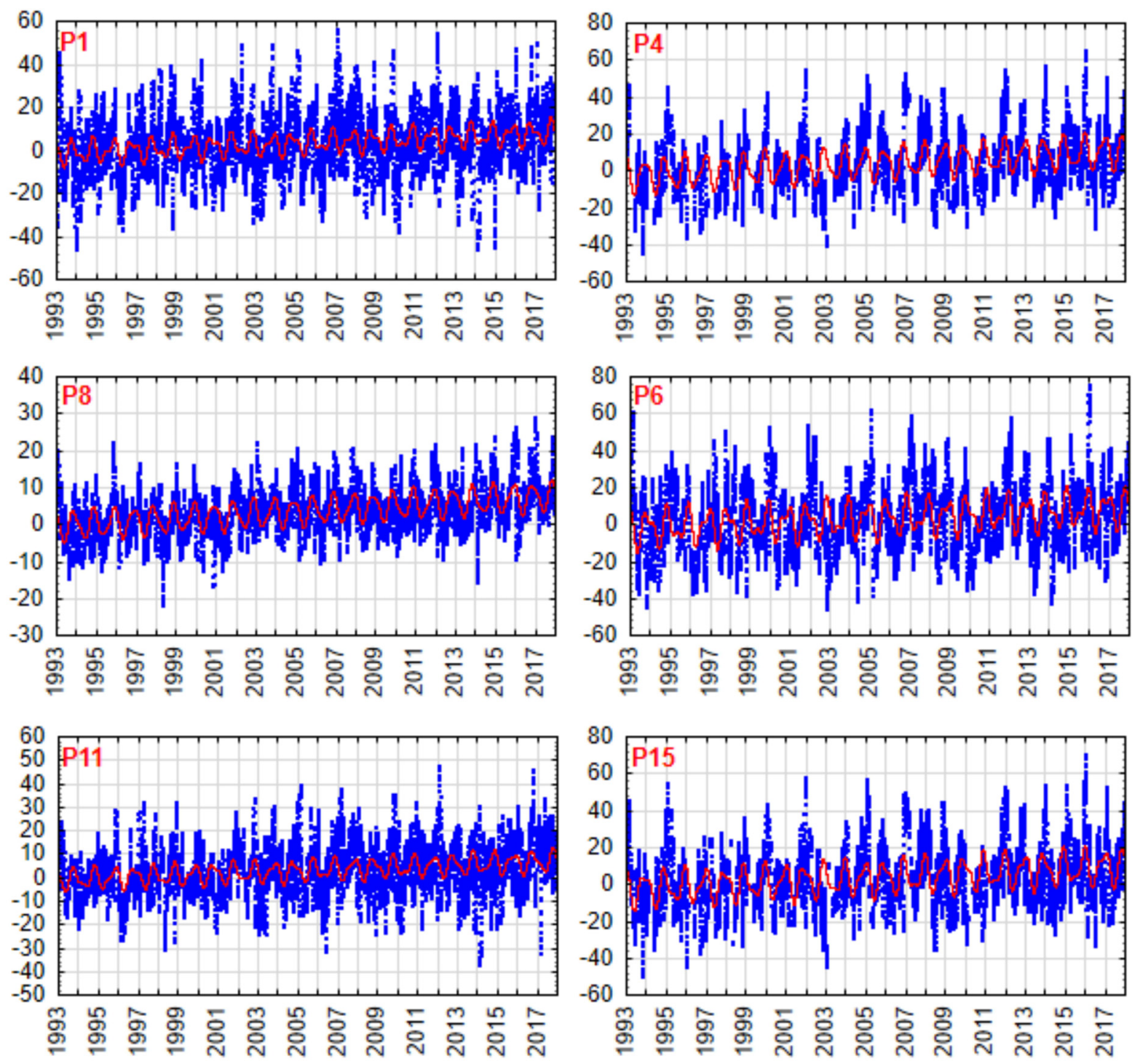

Fig. 4 Time series for the period 1993-2017 of the daily sea level anomaly (blue dots) and time series of the daily sea level anomaly without annual and semi-annual signals (red line).

The annual amplitudes at all characteristic locations range from $3.69 \pm 0.72 \mathrm{~cm}$ to $8.31 \pm 1.88 \mathrm{~cm}$ and the annual phase range from -24.36 to -82.79 in the satellite altimetry results. The results show that the semi-annual amplitudes range from $0.65 \pm 0.13 \mathrm{~cm}$ to $5.28 \pm 1.03 \mathrm{~cm}$ and the semi-annual phases range from 16.38 to 39.81 . The annual amplitude of the results of the satellite altimetry analysis is smaller in the west Baltic area. For the annual phase, the results of the satellite altimetry analysis in the east Baltic area have smaller deviations compared to those from the results of the satellite altimetry analysis in the west Baltic area.

The annual cycles in sea level variations measured by altimetry reach maximum values in approximately the same month (November/December); only in two locations (P5, P13 - west Baltic area) the annual cycles occur in
October. The sea level anomalies determined from the satellite altimetry and the fitted seasonal variations are displayed in Figure 4.

The satellite altimetry time series and the fitted seasonal curves were successfully fitted. In addition, relevant seasonal variations were observed.

\section{DISCUSSION}

Long-term measurements are required to understand ongoing and future sea level changes; therefore, one must continue to perform coastal tide gauge measurements with the use of the satellite altimetry.

There are many climate processes that cause contemporary relative sea level to vary, especially along coastlines; these processes include changes in the regional circulation, land ice and water redistribution and ground subsidence. The various 
factors controlling sea level differ from place to place. In addition, the regional sea level variations are linked with water mass exchange between the Baltic and North seas, which affect water balance, and oceanographic processes in the Baltic Sea. The meteorological variables such as temperature, precipitation, river run-off, and wind stress are also correlated with regional sea level variability.

Lehmann et al. (2011) argue in their article that since the late 1980 s, the winter season (i.e. December to March) of the Baltic Sea area has tended to be warmer, with less ice coverage and warmer sea surface temperatures, which is particularly pronounced in the northern parts of the Baltic Sea. In the paper of Pajak and Kowalczyk (2018) we state that the water temperature has increased by about $0.62{ }^{\circ} \mathrm{C}$ in the period 2005-2010.

Only few studies of the sea level variability have been performed using altimeter data, e.g. Stramska and Chudziak (2013) investigated the temporal sea level variability at some locations in the open Baltic Sea; when available multimission satellite altimetry data were used to estimate the multiyear trend in the Baltic Sea level, the estimated trend was about $0.33 \mathrm{~cm} / \mathrm{yr}$. Donner et al. (2012) in their work demonstrate that quantile regression (QR) shows that the general variability of Baltic sea-level has increased over the last decades.

The trend in the Polish coastal zone locations is in the range between $3.7 \pm 0.2 \mathrm{~mm} / \mathrm{yr}$ in the Swinoujscie and $4.4 \pm 0.2 \mathrm{~mm} / \mathrm{yr}$ in the Gdansk (Pajak and Kowalczyk, 2018). However, the annual cycles in the sea level variations measured by altimetry reach maximum values in approximately the same month (November/December).

In this article, the research results have revealed substantial regional deviations in sea level depending on latitude and longitude.

Variations in a regional sea level observed by the satellite altimetry may be largely caused by variations in the ocean density field, which is driven mostly by changes in the heat content and other factors. However, the freshwater changes can also be essential in changing a regional sea level. The variations in temperature and salinity are caused by changes in the ocean circulation, which in turn results from the forcing of surface wind and therefore can have a large impact on sea level changes. The biggest trend occurs at points which are located in the northern part of the Baltic Sea, while the smallest trends occur at points located in the western part of the Baltic Sea. The average trend is $4.1 \pm 0.2 \mathrm{~mm} / \mathrm{yr}$. All this confirms that monitoring how trends change in the Baltic Sea basin is very important. The annual cycles in sea level variations measured by altimetry reach maximum values in approximately the same month (November/December) in almost all of the points with the exception of two points located in the western part of the Baltic Sea, where the annual cycles occur in October.

\section{CONCLUSIONS}

In this paper, the sea level variations in the Baltic Sea region are investigated from satellite altimetry. The OptD method was used to identify characteristic points from the analyzed data set. This investigation has led to the following results.

The application of the OptD method can reduce the time and cost of satellite altimetry data set processing, which, in turn, enable effective analysis of the acquired information resources.

It is also very important that the OptD method provides total control over the number of points in the data set. Consequently, the time series of satellite altimetry present almost similar behavior in the sea level change in all characteristic locations. We find that there occur substantial regional deviations in sea level depending on the location in the Baltic Sea. The linear change is highest in the northern part of the Baltic Sea, while it is the lowest in the area of the southern part of the Baltic Sea. The average sea level increases by $4.1 \pm 0.2 \mathrm{~mm} / \mathrm{yr}$. The annual cycles of sea level variations measured by the altimetry reach maximum values in approximately the same months of October, November and December in the all characteristic points. This study demonstrates that the satellite altimetry can be used for sea level variability studies at the Baltic Sea region. The methodology applied in this paper is applicable to identify characteristic points, which can be used for the investigation of sea level variations.

\section{REFERENCES}

Ablain, M., Cazenave, A., Larnicol, G., Balmaseda, M., Cipollini, P., Faugère, Y., Fernandes, M.J., Henry, O., Johannessen, J.A., Knudsen, P. et al.: 2015, Improved sea level record over the satellite altimetry era (19932010) from the climate change initiative project. Ocean Sci., 11, 67-82. DOI: 10.5194/os-11-67-2015

AVISO+ HANDBOOKS: 2018, SSALTO/DUACS experimental products handbook. SALP-MU-P-EA23172-CLS, edition 1.0, May 2018.

Błaszczak-Bąk, W.: 2016, New optimum dataset method in LiDAR processing. Acta Geodyn. Geomater., 13, 4(184), 379-386. DOI: 10.13168/AGG.2016.0020

Błaszczak-Bąk, W., Sobieraj-Żłobińska, A. and Kowalik, M.: 2017, The OptD-multi method in LiDAR processing. Meas. Sci. Technol., 28, 7, 075009. DOI: 10.1088/1361-6501/aa7444

Donner, R.V., Ehrcke, R., Barbosa, S.M., Wagner, J., Donges, J.F. and Kurths, J.: 2012, Spatial patterns of linear and nonparametric long-term trends in Baltic Sea level variability. Nonlinear Proc. Geoph., 19, 1, 95-111. DOI: 10.5194/npg-19-95-2012

Douglas, D.H. and Peucker, T.K.: 1973, Algorithms for the reduction of the number of points required to represent a digitized line or its caricature. Cartographica, 10, 2, 112-122. DOI: 10.3138/FM57-6770-U75U-7727

Chambers, D.P., Cazenave, A., Champollion, N., Dieng, H., Llovel, W., Forsberg, R., von Schuckmann, K. and Wada, Y.: 2017, Evaluation of the global mean sea level budget between 1993 and 2014. Surv. Geophys., 38, 309-327. DOI: 10.1007/978-3-319-56490-6_14 
Fu, L.-L. and Haines, B.J.: 2012, The challenges in longterm altimetry calibration for addressing the problem of global sea level change. Adv. Space Res., 51, 1284-1300. DOI: 10.1016/j.asr.2012.06.005

Holgate, S.J., Matthews, A., Woodworth, P.L., Rickards, L.J., Tamisiea, M.E., Bradshaw, E., Foden, P.R., Gordon, K.M., Jevrejeva, D. and Pugh, J.: 2013, New data systems and products at the permanent service for mean sea level. J. Coast. Res., 29, 3, 493-504. DOI: 10.2112/JCOASTRES-D-12-00175.1

Hünicke, B., Zorita, E. and von Storch, H.: 2017, The challenge of Baltic Sea level change. IN: Harff, J., Furmańczyk, K. and von Storch, H. (eds), Coastline changes of the Baltic Sea from South to East. Coastal Research Library book series, vol 19, Springer, Cham, $37-54$.

Legeais, J.-F., Ablain, M., Zawadzki, L., Zuo, H., Johannessen, J.A., Scharfenberg, M.G., FenoglioMarc, L., Fernandes, M.J., Andersen, O.B., Rudenko, S., Cipollini, P., Quartly, G.D., Passaro, M., Cazenave, A. and Benveniste, J.: 2018, An improved and homogeneous altimeter sea level record from the ESA Climate Change Initiatve. Earth Syst. Sci. Data, 10, 281-301. DOI: 10.5194/essd-10-281-2018

Legeais, J.-F., Ablain, M. and Thao, S.: 2014, Evaluation of wet troposphere path delays from atmospheric reanalyses and radiometers and their impact on the altimeter sea level. Ocean Sci., 10, 893-905. DOI: $10.5194 /$ os-10-893-2014

Lehmann, A., Getzlaff, K. and Harlass, J..: 2011, Detailed assessment of climate variability in the Baltic Sea area for the period 1958 to 2009. Clim. Res., 46, 2, 185-196. DOI: $10.3354 /$ cr00876

Pajak, K. and Kowalczyk, K.: 2018, Assessment of the dynamics of sea level and physical phenomena in the Baltic Sea. Geodetski vestnik, 62, 3, 430-444. DOI: 10.15292/geodetski-vestnik.2018.03.430-444

Pajak, K. and Kowalczyk, K.: 2019, A comparison of seasonal variations of sea level in the southern Baltic Sea from altimetry and tide gauge data. Adv. Space Res., 63, 5, 1768-1780. DOI: $10.1016 /$ j.asr.2018.11.022

Peltier, R.: 2004, Global glacial isostasy and the surface of the ice-age earth: the ICE-5G (VM2) model and GRACE. Annu. Rev. Earth Planet. Sci., 32, 111-149. DOI: 10.1146/annurev.earth.32.082503.144359
Peltier, W.R., Argus, D.F. and Drummond, R.: 2015, Space geodesy constrains ice-age terminal deglaciation: The global ICE-6G_C (VM5a) model. J. Geophys. Res. Solid Earth, 120, 450-487. DOI: $10.1002 / 2014 J B 011176$

Pollock, D.S.G.: 2008, Statistical Fourier analysis: Clarifications and interpretations. Working Paper No. 08/36. J. Time Ser. Econom., $1,1$. DOI: $10.2202 / 1941-1928.1004$

Rocco, F.V.: 2016, Sea level trends in the Mediterranean from tide gauges and satellite altimetry. Laurea magistrale, Università di Bologna, Corso di Studio in Fisica del sistema terra [LM-DM270].

Snoeijs-Leijonmalm, P. and Andrén, E.: 2017, Why is the Baltic Sea so special to live in? IN: SnoeijsLeijonmalm, P., Schubert, H. and Radziejewska, T. (eds), Biological Oceanography of the Baltic Sea. Springer, Dordrecht, 23-84. DOI 10.1007/978-94-007-0668-2_2

Spada, G. and Galassi, G.: 2012, New estimates of secular sea level rise from tide gauge data and GIA modelling. Geophys. J. Int., 191, 3, 1067-1094. DOI: $10.1111 / \mathrm{j} .1365-246 X .2012 .05663 . \mathrm{x}$

Stammer, D., Cazenave, A., Ponte, R.M. and Tamisiea, M.E.: 2013, Causes for contemporary regional sea level changes. Annu. Rev. Mar. Sci., 5, 21-46. DOI: 10.1146/annurev-marine- 121211-172406

Steffen, H. and Wu, P.: 2011, Glacial isostatic adjustment in Fennoscandia review of data and modelling. J. Geodyn., 52, 3, 169-204. DOI: $10.1016 /$ j.jog.2011.03.002

Stramska, M. and Chudziak, N.: 2013, Recent multiyear trends in the Baltic Sea level. Oceanologia, 55, 2, 319-337. DOI:10.5697/oc.55-2.319

von Schuckmann, K., Le Traon, P.-Y., Smith, N., Pascual, A., Brasseur, P., Fennel, K. et al. (eds.): 2018, Copernicus Marine Service Ocean State Report. J. Oper. Oceanogr., 11, sup 1, S1-S142. DOI: 10.1080/1755876X.2018.1489208

Wöppelmann, G., Letetrel, C., Santamaria-Gomez, A., Bouin, M.-N., Collilieux, X., Altamimi, Z., Williams, S.D.P. and Marti Miguez, B.: 2009, Rates of sea-level change over the past century in a geocentric reference frame. Geophys. Res. Lett., 36, L12607. DOI: $10.1029 / 2009$ GL038720 